\title{
CORRESPONDENCE
}

\section{Isolated pods of subaqueous welded ash-flow tuff: a distal facies of the Capel Curig Volcanic Formation (Ordovician), North Wales}

SIRS - The Capel Curig Volcanic Formation (Howells \& Leveridge, 1980) includes welded ash-flow tuffs that were erupted subaerially, crossed a littoral area, and were subaquaeously emplaced on marine sediments (Francis \& Howells, 1973; Howells et al. 1979). Kokelaar (1982) suggested that the lobate bases of tuffs around Capel Curig were formed by fluidization-facilitated collapse of hot tuff into wet sediments. Howells, Campbell \& Reedman (1985) describe a distal facies of these rocks consisting of isolated pods of welded tuff in shallow marine sediments, with no overlying continuous ash-flow tuff sheet.

The scenario Howells, Campbell \& Reedman (1985) envisage as having produced the features described involves two independent mechanisms operating simultaneously to generate discrete pods from an ash-flow sheet: (1) fluidization-facilitated downward protrusion leading to the isolation of some tuff pods, for example those underlying the Garth Tuff; and (2) a mechanism involving a polylobate front of a waning ash-fiow crossing a fault-induced topographic feature causing the budding off of small tuff bodies which flowed downslope from the edge of the sheet.
However no sedimentological record of contemporaneous faulting has been proved from the facies of the Capel Curig Volcanic Formation. It seems that the second mechanism invokes special pleading in the absence of independent evidence for the required palaeotopography if the first mechanism could produce all the features described both around Capel Curig and in the distal facies.

Distal parts of a pyroclastic flow that has not ponded may have less ash supplied relative to proximal parts for the following reasons: (1) widening dispersal (fanning out) of the flow; (2) material erupted during the waning stages of eruption may have insufficient momentum to reach distal portions; (3) ash is sedimented or elutriated during flow; (4) in the case of the subaqueous flows considered, material has been emplaced into sediment as lobes at the base of the flow nearer source. The distal end of a subaqueously deposited high-grade ignimbrite (sensu Walker, 1983), although considerably thinner than its proximal equivalent, will still be very hot, and may invade underlying wet sediments. Immediately on passage of the hot flow a steam carapace will encroach just below the surface of the wet sediment. Once

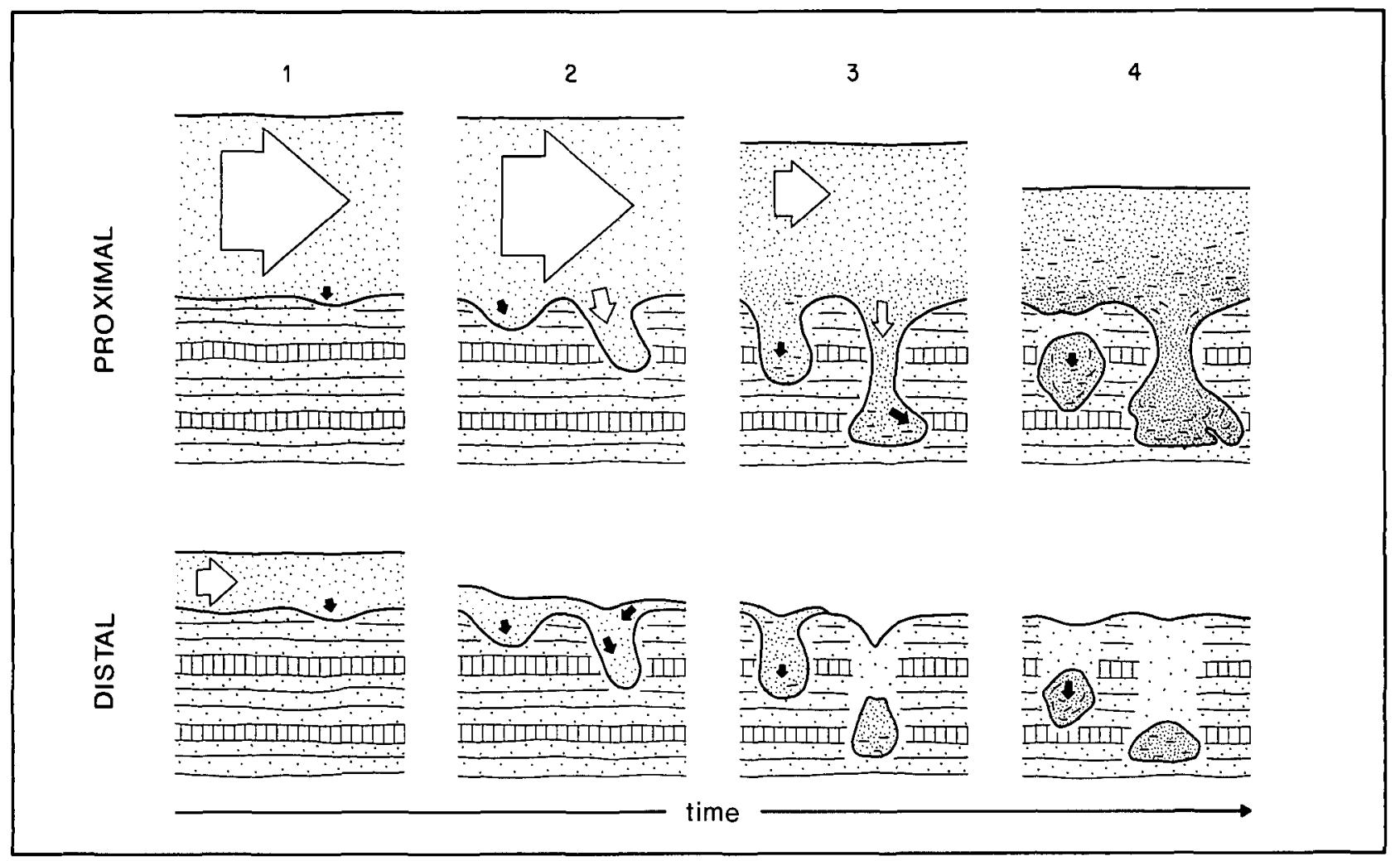

Figure 1. Sequence of pod formation and collapse accompanying the passage of a hot pyroclastic flow over wet sediment. Arrows indicate pyroclast movement. Escaping fluidized sediment not shown. Stage 1: Initial passage of the flow. Interface irregularities are exploited with increasing rapidity until by Stage 2 interface migration is concentrated on discrete points and these sprout downwards. Distally the supply of new material dwindles and the flow thins. Stage 3: Towards the end of eruption the flow deflates but distally material lost is not replenished and the remaining surface tuff drains down. Stage 4: End of eruption. Continuing deflation, compaction and welding. If hot enough, pods continue to descend and become detached if supply from surface is curtailed due to increasing viscosity or due to lack of surface material. Pods arrested before onset of welding compaction show no distortion of welding foliation. 
an irregularity occurs at this interface it will be exploited, since an ash layer fractionally thicker at one point than another will exert fractionally more load at that point. A subtle difference in pressure is significant where a fluidization carapace prevents the sediments from offering significant resistance. Thus the interface migrates downward and soon the formerly slight inequality of load is magnified, ash rapidly draining down into the growing protrusion (Fig. 1). Depth of protrusion can be limited by cooling of the tuff, attainment of critical pressure (not realized in the shallow depths of Capel Curig Volcanic Formation deposition), cohesiveness and water content of sediment, and the attainment of hydrostatic equilibrium. A large head of surface ash is not required.

Towards the thin cistal edge of an ignimbrite there will come a point where ash draining into lobes in the sediment is not replenished sufficiently to maintain a continuous surface cover. From here to the distal limit of the ash-flow, the ignimbrite will be composed entirely of isolated pods which have sunk to various levels. This is analogous to the foundering and collapse of an entire sandstone bed to form isolated pseudonodules (load balls) by Rayleigh-Taylor instability in liquified sediments (Allen, 1982). Probably many more pods were formed than have been mapped between Bala and Capel Curig. Some may lie above or below the present erosion surface or be obscured by drift. The geographical distribution and combined volume of pods formed would indicate the dimensions of a parent ash-flow sheet which may have given rise to a normal ignimbrite of wedge-shaped profile had there not been wet sediment interaction. Since pod location would have been influenced by interaction between any subtle inhomogeneities or irregularities on the sea bed, and variations within the flow such as a polylobate flow front, the boundary between a continuous ignimbrite sheet and the isolated pods would be diffuse. This appears to be the case in the Capel Curig rocks. Indeed the relatively thin Racks Tuff is already discontinuous one kilometre west of Capel Curig to the north of the fault at Dolwyddelan.

\section{References}

I AlLen, J. R. L. 1982. Sedimentary Structures. Their Character and Physical Basis, volume 2. Amsterdam: Elsevier, $663 \mathrm{pp}$.

Francis, E. H. \& Howells, M. F. 1973. Transgressive welded ash-flow tuffs among the Ordovician sediments of N.E. Snowdonia. Journal of the Geological Society of London 129, 621-41.

Howells, M. F., Campbell, S. D. G. \& Reedman, A. J. 1985. Isolated pods of subaqueous welded ash-flow tuff: a distal facies of the Capel Curig Volcanic Formation (Ordovician), North Wales. Geological Magazine 122, 175-80.

Howells, M. F. \& Leveridge, B. E. 1980. The Capel Curig Volcanic Formation. Report. London: Institute of Geological Sciences No. 83/1, 23 pp.

Howells, M. F., Leveridge, B. E., Addison, R., Evens, C. D. R. \& NutT, M. J. C. 1979. The Capel Curig Volcanic Formation, Snowdonia, North Wales: variations in ash flows related to emplacement environment. In The Caledonides of the British Isles - Reviewed (ed. A. L. Harris, C. H. Holland and B. E. Leake) pp. 611-618. Special Publication of the Geological Society of London, no. 8.

KokelaAR, B. P. 1982. Fluidization of wet sediment during the emplacement of various igneous bodies. Journal of the Geological Society of London 139, 21-33.
WALKER, G. P. L. 1983. Ignimbrite types and ignimbrite problems. Journal of Volcanology and Geothermal Research 17, 65-88.

\section{J. BRANNEY}

Department of Geology

University of Sheffield

Mappin Street

SHEFFIELD

S1 3JD

\section{September 1985}

\section{Reply}

SIRS - We welcome Mr Branney's presentation of an alternative model for the formation of the isolated pods of welded ash-flow tuff within the Capel Curig Volcanic Formation. Both Mr Branney's and our models ascribe a key role to film boiling and fluidization of sediment at the basa contact of the ash-flow tuff during the emplacement of the pods into the substrate and we agree that it is an attractive proposition to invoke a single mechanism to explain both pods subjacent to the parent ash-flow sheet and beyond the distal limits of the main sheet. In our original proposal we suggested that a second mechanism, flow disruption, was required to explain the distribution of the isolated pods and though we accept that we were unable to present conclusive evidence for the existence of the fault controlled slope invoked as a factor promoting flow disruption, we still see problems in accepting Mr Branney's more simple model in its entirety.

Two points are particularly relevant. Firstly, there is an abrupt change from the continuous sheet facies to the totally isolated pod facies, whereas the relationship envisaged in Branney's figure 1 suggests there should be a gradual transition. Secondly, though we concur that, due to limitations of exposure and the regional structure, only a proportion of the total number of pods are currently exposed, nevertheless the relatively large separation of the more distal pods is real. The most distal pod that we have so far recognized (SH 92884573 ) is a tabular poorly welded body about $4 \mathrm{~m}$ thick and over $1.5 \mathrm{~km}$ from its nearest neighbour. We find it hard to envisage that 'drainage' of a once continuous parent sheet into the scattered distal pods was totally efficient over the substantial areas demanded by the distribution of the most distal pods. Accordingly, while we accept that concentrated groups of pods situated very close to the limit of the continuous ash-flow sheet can be explained by Branney's model, we believe that an additional mechanism which resulted in the primary deposition of isolated areas of tuff, prior to the downward migration of the pods, is required to explain the extreme isolation of the more distal pods.

For those who might doubt the basic supposition upon which either model rests, namely the correlation of the isolated tuff pods with one or other of the continuous ash-flow tuff sheets of the Capel Curig Formation, we would add that trace element studies currently in progress confirm correlation of the pods with the lowest and most extensive of the ash-flow tuff units, the Garth Tuff.

\section{F. HOWELLS S. D. G. CAMPBELL}

\section{A. J. REEDMAN}

British Geological Survey

Bryn Eithyn Hall

Llanfarian Aberystwyth

Dyfed SY23 4BY

7 November 1985 